\title{
5S APPLICATION TRAINING (SEIRI, SEITON, SEISŌ, SEIKETSU, AND SHITSUKE) TO IMPROVE THE QUALITY OF WORK ENVIRONMENT IN THE SERVICE INDUSTRY
}

\author{
Humiras Purba, Dana Santoso, Jakfat Haekal \\ Universitas Mercu Buana Jakarta, Indonesia.
}

\begin{abstract}
National industries already have policies that are able to strengthen industrial competitiveness, especially small and medium businesses. Business activities in the form of manufacturing Small Industries are the backbone of the real economy that encourages the welfare of the community because the numbers are very large and spread in various regions. because it is generally close to residential and business centers. National policies that can encourage competitiveness, for example, are carried out in the form of soft loans, training, incentives, tax breaks, business assistance, ease of regulation and various forms of support. But it must be understood that what is no less important is how the small manufacturing industry itself can make competitive steps both in capturing markets and in the efficient form of work operations within its organization. At present, the 5S method (Seiri, Seiton, Seisō, Seiketsu, and Shitsuke) has been widely adopted by various industries in various countries. The 5S method (Seiri, Seiton, Seisō, Seiketsu, and Shitsuke) was first introduced in Japan as a determination to conduct sorting (Seiri), structuring (Seiton), cleansing (Seisō), maintaining steady conditions (Seiketsu), and self-awareness of the habits needed to carry out work well (Shitsuke). The implementation of community service activities in the form of socialization and training on the application of 5S (Seiri, Seiton, Seisō, Seiketsu, and Shitsuke) to improve the quality of the work environment in the service industry is packaged in the form of simple, easy to understand concepts planned for three months.
\end{abstract}

Keywords: 5S, Service Industry, Quality

\section{INTRODUCTION}

Small and Medium Industries (IKM) or known as Micro, Small and Medium Enterprises (MSMEs) have an important and strategic role in national development. Besides playing a role in economic growth and employment, MSMEs also have other roles such as distributing development results. So that the government proves special attention to MSMEs by launching Law Number 20 Year 2008 concerning Micro, Small and Medium Enterprises (MSMEs).

Small industries often underestimate the workplace as a means of creating income. Small industries place more emphasis on and value other sectors such as financial management, marketing and sales, and product development. Sometimes small industries often pay less attention to the most basic things, namely work areas, where these basic things can also affect the quality and productivity of small industries. Small industries are said to be good when making work areas more organized. In addition to making the work area more organized, another fundamental thing for the work area to keep running well is to maintain the workplace. A bad work environment causes productivity to be low so that it will have an impact on the quality of the product produced. Production targets and plans cannot be realized, if the elements of productivity which include quality, efficiency, and effectiveness are of low value then the company's productivity will automatically become low. Therefore, it is necessary to apply 5S (Seiri, Seiton, Seisō, Seiketsu, and Shitsuke) to improve the quality of the work environment in small industries.

According to Osada (2014) The meanings of 5S are Seiri (Election), Seiton (Arrangement), Seisō (Cleansing), Seiketsu (Consolidation) and Shitsuke (Habituation). 5S method is a method that can be used for the purpose of creating and maintaining the quality of the work environment in an organization. The understanding of $5 \mathrm{~S}$ philosophy (Vera Devani, 2016) namely;

a. Seiri, that is, set aside unnecessary items with those that need or set aside and discard unnecessary items at work. 
b. Seiton (stacking), which is arranging work tools that are used neatly and completely eliminates the activity of looking for tools that can be easily found quickly.

c. Seisō, which is maintaining the cleanliness of the workplace.

d. Seiketsu, which is maintaining Seiri, Seiton, and Seisō in order to continue continuously.

e. Shitsuke, namely as a discipline and really become a habit, so that workers are accustomed to obeying regulations and counseling is held for workers to work professionally.

The benefits of implementing $5 \mathrm{~S}$ in general, will produce various benefits for the industry such as increasing teamwork morale, a cleaner, neat and orderly workplace, a safer and more comfortable work environment, optimal use of work space, simplifying routine maintenance, establishing work standards obviously, more effective inventory control, reduce operating costs, improve company image, reduce customer complaints (Suwondo, 2012).

Through community service programs, Mercu Buana University especially the Industrial Engineering Masters Study Program tries to participate in developing the competitiveness of IKM in West Jakarta especially North Meruya by trying to socialize and carry out $5 \mathrm{~S}$ implementation training (Seiri, Seiton, Seisō, Seiketsu, and Shitsuke) to improve the quality of the work environment in the Meruya Utara service industry.

Based on field observations and preliminary surveys in the service industry the problems encountered related to the application of $5 \mathrm{~S}$ (Seiri, Seiton, Seisō, Seiketsu, and Shitsuke) to improve the quality of the work environment in the service industry are as follows:
a. How do you identify the problems in the service industry work environment?
b. How is $5 \mathrm{~S}$ implemented in improving the quality of the work environment in the service industry?
c. What are the results of the evaluation after the $5 \mathrm{~S}$ implementation in improving the quality of the work environment in the service industry?

\section{METHODS}

The priority target audience is service industry players in Meruya Utara Kelurahan, Kembangan District, West Jakarta. The results of the questionnaire distributed earlier found that small-scale industrial manufacturing businesses were quite widespread in Meruya Utara Village, West Jakarta. In this community service activity, the priority of the activity proposed by the proposer is the quality aspect of the work environment in accordance with the competence of the proposer from the Industrial Engineering Masters Program. More specifically aspects that are addressed in the quality of the work environment by using the application of 5S (Seiri, Seiton, Seisō, Seiketsu, and Shitsuke) are expected to have a positive impact on the service industry namely (Listiani, 2014):

a. Everyone will be able to find the problem faster.

b. Everyone will give attention and emphasis at the planning stage.

c. Supports process-oriented thinking.

d. Everyone will concentrate on more important and urgent problems to be solved.

e. Everyone will participate in building a new system.

f. Minimizing the potential for accidents (work accidents), breakdown (damage disorder), cost (costs), and defects (defective products).

g. Increase efficiency and morale.

h. Organizations that are ready to follow changes according to the direction of thE leadership strategy.

\section{Activity Method}

The method of activities that will be used in the socialization and training activities on $5 \mathrm{~S}$ implementation (Seiri, Seiton, Seisō, Seiketsu, and Shitsuke) to improve the quality of the work environment in the Meruya Utara service industry are as follows:

a. Field observations to several IKM locations

This step is carried out to identify real problems that are considered inefficient in improving the quality of the work environment.

b. Varied Lectures and Discussion Questions and Answers

This method was chosen to convey important concepts to understand how important the quality of the work environment is. The use of this method with the consideration that the lecture method combined with audio and video can provide material that is relatively easy to understand, compact, fast and easy. The material is 
given the concept and implementation of $5 \mathrm{~S}$ methods (Seiri, Seiton, Seisō, Seiketsu, and Shitsuke) in the service industry.

c. Questionnaire (Pre-test and Post-Test)

Participants in the manufacturing industry will be asked to actively participate in filling out the questionnaire both at the initial stage (before the activity) and the final stage after the completion of the socialization activities and 5S implementation (Seiri, Seiton, Seisō, Seiketsu, and Shitsuke) related to the knowledge and insights of the Kelurahan service industry Meruya Utara about the importance of improving the quality of the work environment in the Meruya Utara service industry.

d. Counseling and Discussion of Questions and Answers

Counseling about improving the quality of the work environment with the $5 \mathrm{~S}$ method (Seiri, Seiton, Seisō, Seiketsu, and Shitsuke) namely problem identification, analysis of potential improvement in improving the quality of the work environment and the strategy of implementing the $5 \mathrm{~S}$ method (Seiri, Seiton, Seisō, Seiketsu, and Shitsuke). After counseling, discussion and questions and answers will be provided.

e. Self-assessment

This method was chosen to give participants the ability to assess conditions and adverse impacts on the work environment of the Meruya Utara service industry. The self-assessment will be guided by the instructor and will be divided into two groups which will be given the opportunity to conduct an assessment in cases of improving the quality of the work environment.

\section{f. Exercise}

This method is used to provide an opportunity for each participant in designing future improvements with the 5S method (Seiri, Seiton, Seisō, Seiketsu, and Shitsuke) and how to implement and monitor.

\section{DISCUSION AND RESULT}

After the dedication activity, a questionnaire will be distributed to determine the level of understanding of participants towards:

a. The level of understanding of the concept of 5S (Seiri, Seiton, Seisō, Seiketsu, and Shitsuke) in the service industry.

b. Ability to do self-assessment and identify improvement.

c. Potential implementation of $5 \mathrm{~S}$ concepts (Seiri, Seiton, Seisō, Seiketsu, and Shitsuke) in the service industry.

d. The level of satisfaction with the implementation of community service.

e. Willingness as a sustainable fostering partner of UMB.

\section{REFERENCES}

Osada T. 2004. Sikap Kerja 5S. Jakarta: PPM.

Vera Devani \& Ade Fitra. 2016. Analisis Penerapan Konsep 5S di Bagian Proses Maintenance PT. Traktor Nusantara. Jurnal Hasil Penelitian dan Karya Ilmiah dalam Bidang Teknik Industri Vol. 2, No. 2. UIN Sultan Syarif Kasim Riau.

Suwondo, C. Penerapan Budaya Kerja Unggulan 5S (Seiri, Seiton, Seisō, Seiketsu, dan Shitsuke) di Indonesia. Jurnal Magister Manajemen. Vol. 1 No. 1 Hal. 29-48. April 2012.

Listiani, T. Penerapan Konsep 5S dalam Upaya Menciptakan Lingkungan Kerja yang Ergonomis di STIA LAN Bandung. Jurnal Ilmu Administrasi. Vol. 7 No. 3 Hal 2014-2014, September 2010. 